\title{
Effect of Stage, Season and Parity of Lactation on Milk Composition in Gir Cattle
}

\author{
P.U. Gajbhiye ${ }^{1^{*}}$, A.R. Ahlawat ${ }^{2}$, H.A. Sharma ${ }^{2}$ and S.S. Parikh ${ }^{3}$ \\ ${ }^{1}$ Department of Animal Genetics \& Breeding, Arawali Veterinary College, RAJUVAS, \\ Sikar-332001, India \\ ${ }^{2}$ Department of Animal Genetics \& Breeding, College of Veterinary Science \& A. H., \\ Junagadh Agricultural University, Junagadh-362001, India \\ ${ }^{3}$ Cattle Breeding Farm, Junagadh Agricultural University, Junagadh-362001, India
}

*Corresponding author

A B S T R A C T

\begin{tabular}{|l|}
\hline Ke y w o r d s \\
Gir, Milk \\
composition, Non- \\
genetic factors
\end{tabular}

A total of 1649 milk samples from 172 Gir cows of Cattle Breeding Farm, Junagadh Agricultural University were collected with fortnight interval throughout the lactation for a period from 04-04-2014 to 10-10 -2015. The samples collected were analyzed for estimation of Fat \%, SNF \%, and Protein \% and Sugar (Lactose). Total period was grouped in four seasons: Rainy, Winter, Spring and Summer. Total 11 stages were considered to for analysis. Effect of lactation order was considered as cows in lactation order from 01 to 10 parity were included in the study. All the four constituents, Fat, SNF, Protein and sugar of milk of Gir cows were found to be influenced by season in which milk is produced in lactation. The highest Fat content was observed in milk of animals that produced milk during in Rainy season (4.34 \%) and lowest in Summer season (3.88\%). High climatic temperature during Summer season could cause decline in milk yield and fat percentage due to heat stress. Stage of lactation influenced only Fat content of milk of Gir Cows. While, SNF, Protein and Sugar content were not influenced by stage of lactation.

\section{Introduction}

Gir Cattle is an important breed of Saurashtra region of Gujarat. Milk production in Gir cows has been noticed as high persistent throughout the lactation. Numbers of studies have been made on the persistency of lactation in Gir cows. Composition of milk produced by Gir Cows is of major interest to milk producers and even consumers, because of its relationship with public health and quality issues. Milk is composed of water, fat, protein, sugar (lactose), lipids, fatty acids and minerals. Number of factors influence the milk composition, such as stage of lactation, parity of lactation, season of lactation, availability of feed and fodder, type of concentrate fed etc. However, information on milk composition such as milk fat, solid not fat (SNP) and protein content and sugar content of milk as varying with the advance of lactation i.e. stage of lactation and season of lactation is very scanty in Gir cattle. Milk Composition and stage of lactation are related 
(Looper, M. 2016; Kayastha et al., 2008; Arora and Bhojak, 2013). Variation in milk fat and protein due to advancement of lactation has been reported by Rogers and Stewart (1982). Similar Information in milk of Gir cattle is scanty. Hence, study was carried out to assess the causes of fluctuation in composition of milk.

\section{Materials and Methods}

A total of 1649 milk samples from 172 individual Gir cows of Cattle Breeding Farm, Junagadh Agricultural University were collected with fortnight interval throughout the lactation for a period from 04-04-2014 to 10-10 -2015. The samples collected were analyzed using Lactoscan milk Analyzer for estimation of Fat \%, SNF \%, and Protein \% and Sugar (Lactose). Uniform feeding regime was followed throughout the experimental period in the entire Gir herd. Seasonal variation in the feed $\&$ fodder supplied were considered towards effect season on the milk constituents. Total period was grouped in four seasons: Rainy (July-Sept), Winter (Oct-Dec), Spring (Jan-Mar) and Summer (April-June). Stage of lactation was taken as month of lactation from calving to drying in which milk sample was taken. Total 11 stages were considered to for analysis. Effect of lactation order was considered as cows in lactation order from 01 to 10 parity were included in the study.

Fat $\%, \mathrm{SNF} \%$, Protein $\%$ and Lactose $\%$ for each milk sample on monthly interval of each individual animal throughout lactation period.

The data collected were analyzed for assessing the effect of stage of lactation, season of lactation (Season in which sample were taken) and order of lactation using Least-squares analysis (Harvey, 1987). The data were subjected to square root transformation for statistical analysis.

\section{Results and Discussion}

Season in which sample of milk in a lactation was taken found to influence milk composition in terms of Fat, SNF, CP and Sugar highly Significantly $(\mathrm{P}<0.01)$. This could be due to the effect of seasonal variation in the feed and fodder supply during the year along with the effect of climate on the body physiology. High climatic temperature observed during Summer season could decline in milk yield and fat percentage. Bandarnayaka and Holmes (1976) reported that fat percentage decreased in the heat stressed cows compared to control.

Fat content in the milk produced in all the four Season of sampling differ highly significantly $(\mathrm{P}<0.01)$. The highest Fat being produced in the season - July-Aug-Sept (Rainy cum winter) and lowest in April-May-June (Summer season). Season x Stage of lactation interaction was found to be non-significant. Similar significant $(\mathrm{P}<0.01)$ variation in Fat content of milk due to Season was also reported by Jenness, (1985). Seasonal variations in milk fat percentage are well recognized with Summer months averaging 0.4 percentage unit less than Winter months.

Stage and Parity of lactation was also found to affect the fat content of the milk $(\mathrm{P}<0.05)$.A decrease in milk fat percentage of 0.2 percent over five lactations has been reported by Rogers and Stewart (1982). They also observed that milk fat percentage vary with stage of lactation. The highest percentages are usually found in Colostrum, followed by a decline during first 2 months of lactation, then a slow increase as the lactation progress. Significant effect of stage of lactation on fat percentage was reported by Kayastha et al., (2008) in Assam cattle. Bhoite and Padekar (2002) reported non-significant effect of stage of lactation on Fat in $\mathrm{HF}$ crosses but significant effect in crosses involving Jersey (Table 1 and 2; Fig. 1-3). 
Table 1 Effect of lactation order was considered as cows in lactation order from 01 to 10 parity

\begin{tabular}{|c|c|}
\hline Stage of Lactation (Days) & Stage \\
\hline $0-30$ & 01 \\
\hline $31-60$ & 02 \\
\hline $61-90$ & 03 \\
\hline $91-120$ & 04 \\
\hline $121-150$ & 05 \\
\hline $151-180$ & 06 \\
\hline $181-210$ & 07 \\
\hline $211-240$ & 08 \\
\hline $241-270$ & 09 \\
\hline$>300$ & 10 \\
\hline & 11 \\
\hline
\end{tabular}

Table.2 Least-squares averages for Fat, SNF, Protein and Sugar in milk of Gir Cattle Season wise means for FAT, SNF, Protein, Sugar

\begin{tabular}{|c|c|c|c|c|c|}
\hline Effects & N & FAT & SNF & Protein & Sugar \\
\hline Overall Mean & $\mathbf{1 6 4 9}$ & $\mathbf{4 . 1 5 7}$ & $\mathbf{8 . 8 5 6}$ & $\mathbf{3 . 2 8 3}$ & $\mathbf{4 . 8 3 1}$ \\
\hline Rainy & 439 & 4.343 & 9.150 & 3.396 & 5.040 \\
\hline Winter & 356 & 4.264 & 8.856 & 3.279 & 4.835 \\
\hline Spring & 230 & 4.145 & 8.803 & 3.214 & 4.734 \\
\hline Summer & 624 & 3.884 & 8.637 & 3.250 & 4.717 \\
\hline
\end{tabular}

Stage wise means for FAT, SNF, Protein, Sugar

\begin{tabular}{|c|c|c|c|c|c|}
\hline Effects & $\mathrm{N}$ & FAT & SNF & Protein & Sugar \\
\hline Stage 1(0-30 days) & 185 & 4.141 & 8.856 & 3.294 & 4.857 \\
\hline Stage 2(31-60 days) & 196 & 4.040 & 8.910 & 3.286 & 4.778 \\
\hline Stage 3(61-90 days) & 178 & 4.056 & 8.755 & 3.279 & 4.818 \\
\hline Stage 4(91-120 days) & 172 & 4.120 & 9.138 & 3.272 & 4.84 \\
\hline Stage 5(121-150 days) & 149 & 4.223 & 9.284 & 3.312 & 4.915 \\
\hline Stage 6(151-180 days) & 134 & 4.186 & 8.850 & 3.276 & 4.866 \\
\hline Stage 7(181-210 days) & 124 & 4.251 & 8.862 & 3.323 & 4.892 \\
\hline Stage 8(211-240 days) & 106 & 4.129 & 8.590 & 3.196 & 4.761 \\
\hline Stage 9(241-270 days) & 67 & 3.932 & 8.503 & 3.236 & 4.652 \\
\hline Stage 10(271-300 days) & 72 & 4.347 & 8.773 & 3.326 & 4.870 \\
\hline Stage 11 (>300 days) & 266 & 4.313 & 8.946 & 3.326 & 4.888 \\
\hline
\end{tabular}


Parity wise means for FAT, SNF, Protein, Sugar

\begin{tabular}{|c|c|c|c|c|c|}
\hline Effects & N & FAT & SNF & Protein & Sugar \\
\hline Parity 1 & 468 & 3.996 & 8.749 & 3.229 & 4.796 \\
\hline Parity 2 & 441 & 4.040 & 8.785 & 3.268 & 4.791 \\
\hline Parity 3 & 229 & 4.032 & 8.743 & 3.243 & 4.787 \\
\hline Parity 4 & 229 & 3.873 & 8.602 & 3.186 & 4.635 \\
\hline Parity 5 & 127 & 4.182 & 9.000 & 3.334 & 4.870 \\
\hline Parity 6 & 58 & 3.908 & 9.162 & 3.186 & 4.743 \\
\hline Parity 7 & 51 & 4.276 & 8.880 & 3.286 & 4.937 \\
\hline Parity 8 & 28 & 3.869 & 8.928 & 3.345 & 4.853 \\
\hline Parity 9 & 17 & 4.116 & 8.323 & 2.941 & 4.635 \\
\hline Parity 10 & 01 & 5.382 & 9.603 & 3.478 & 5.29 \\
\hline
\end{tabular}

ANOVA for Fat, SNF, Protein and Sugar content in Gir milk

\begin{tabular}{|c|c|c|c|c|c|}
\hline Effect & d.f. & MS-Fat & MS-SNF & MS-Protein & MS-Sugar \\
\hline Season & 3 & $1.052901^{* *}$ & $0.513890^{* * *}$ & $0.149378^{*}$ & $0.394239^{* *}$ \\
\hline Stage & 10 & $0.094653^{*}$ & 0.133922 & 0.012362 & 0.22798 \\
\hline Parity & 9 & $0.091583^{*}$ & 0.068559 & 0.038020 & 0.039650 \\
\hline SeasonXStage & 30 & 0.065471 & $0.147786^{*}$ & 0.024975 & 0.033690 \\
\hline Remainder & 1596 & 0.045088 & 0.089150 & 0.041951 & $0.021836^{* *}$ \\
\hline
\end{tabular}

$*<0.05, * *<0.01$

Fig.1 Season wise variation in FAT, SNF, Protein and sugar

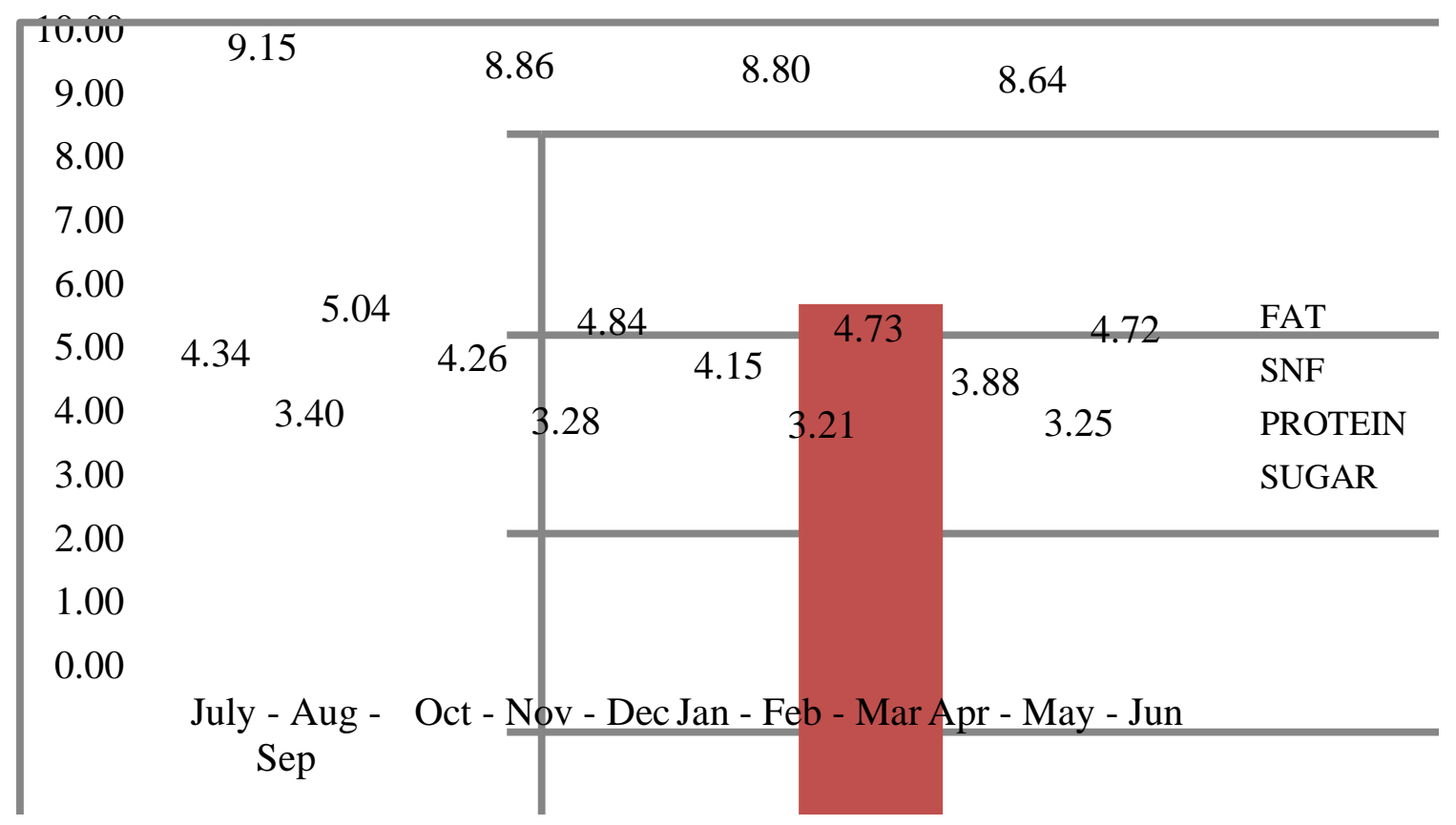


Fig.2 Stage wise variation in FAT, SNF, Protein and sugar

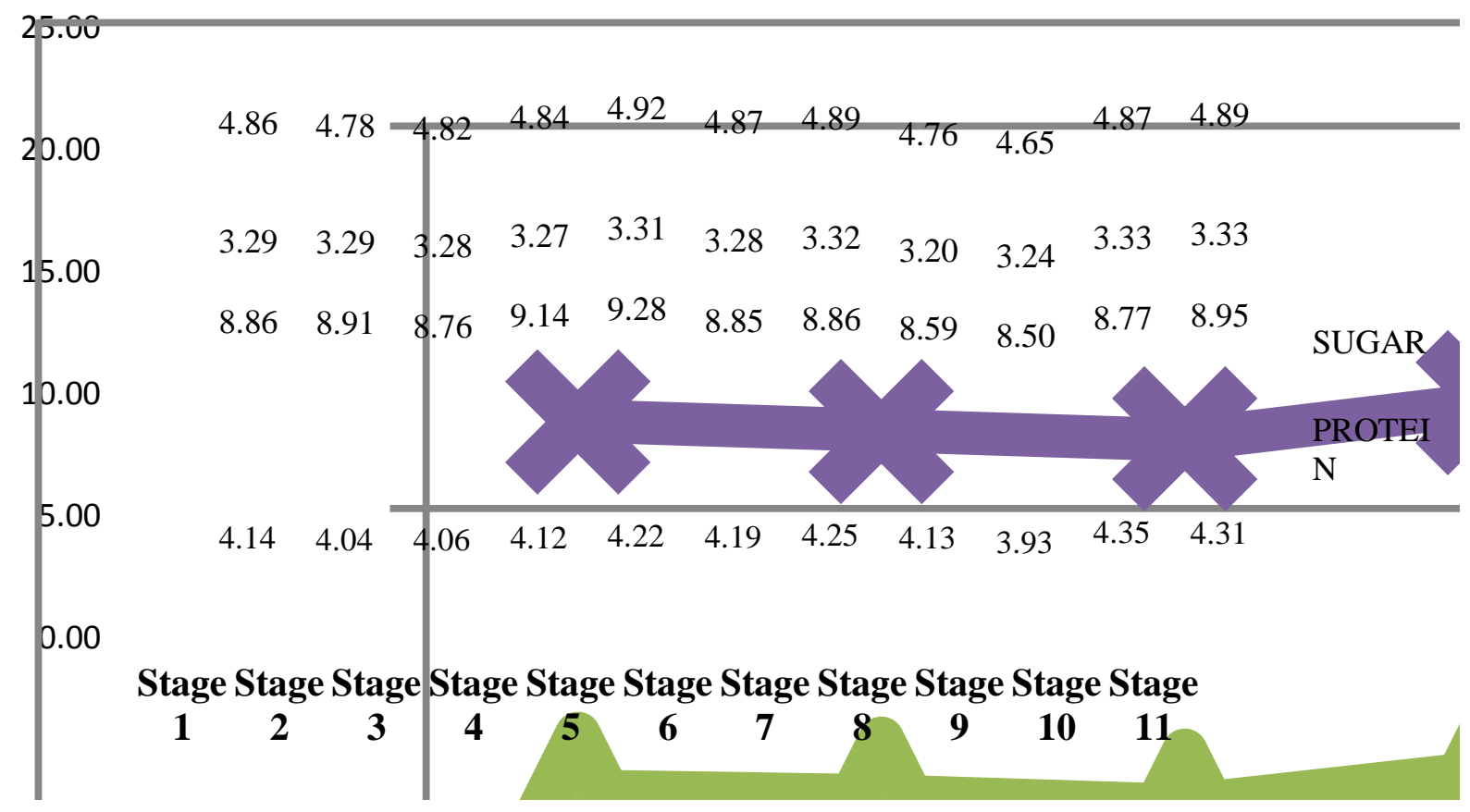

Fig.3 Parity wise variation in FAT, SNF, Protein and sugar

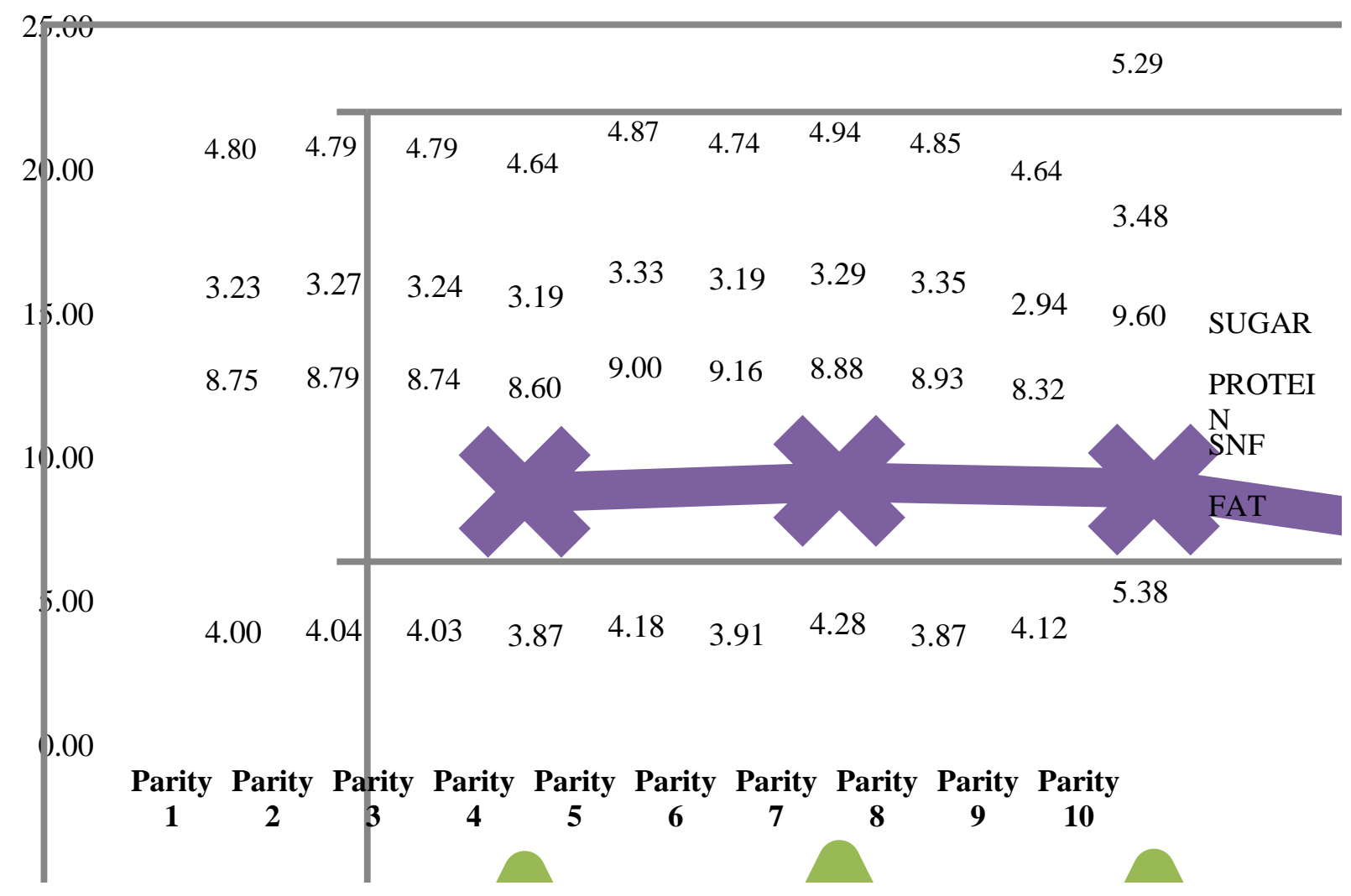


Sarkar (2006) reported that lactation stage had no influence on fat content of milk.

SNF content in the milk of Gir Cows differ highly significantly $(\mathrm{P}<0.01)$ in all the four season of sampling, the highest SNF being observed in the season - July to Sept and Lowest in April- June.

Effect of Stage of lactation and Parity was found to be non-significant on SNF content of milk. Sarkar (2006) observed significant effect of lactation stage on SNF, Protien and Lactose content of milk. However, Kayastha et al., (2008) reported significant effect of Stage of lactation on SNF content in Assam Cattle. However, Season and Stage of lactation interaction effect was found to be significant on SNF.

Milk Protein and milk sugar content in the milk of Gir cows differ highly significantly $(\mathrm{P}<0.01)$ in all the four season of sampling. This was also reported by Jenness (1985), Rogers and Stewart (1982). They observed that age of animal has a significant effect on milk protein percentage and composition in cows.

Influence of Stage of lactation and Parity of lactation was found to be non-significant on Protein and Sugar content of milk. The main biological function of Lactose in milk is the regulation of water content and thus the regulation of osmotic content (Davis et al., 1983; Jenness, 1985).

Because of this function Lactose remains the most constant constituent in milk. Nonsignificant influence of stage of lactation on milk protein was reported by Kayastha et al., (2008) in Assam Cattle.

Interaction effect of Season and Stage was marginal significant $(\mathrm{P}<0.05)$ for sugar and non- significant for protein.
All the four constituents, Fat, SNF, Protein and sugar of milk of Gir cows were found to be influenced by season in which milk is produced in lactation. Seasonal variation in the feed and fodder supply during the year along with the effect of environment on the body physiology during lactation period could be responsible factors affecting milk composition. The highest Fat content was observed in milk of animals that produced milk during July-Sept. (4.34 \%) i.e. in Rainy season and lowest in the April-June. (3.88\%) i.e. in Summer. High climatic temperature observed during Summer season could cause decline in milk yield and fat percentage due to heat stress. Stage of lactation was found to influence only Fat content of milk of Gir Cows. While, SNF, Protein and Sugar content were not influenced by stage of lactation.

\section{References}

Arora, R. and Bhojak, N. 2013. Physiochemical and Environmental factors responsible for change in milk composition of milking animals. Int $J$ Engg Sci, 2(1): 275-277.

Bandaranayaka, D. D. and Holmes, C. W. 1976. Changes in the composition of milk and rumen contents in cows exposed to a high ambient temperature with controlled feeding. Trop Anim. Health Prod, 8: 38-46.

Bhoite, U.Y. and Padekar, R. N. 2002. Factors affecting milk yield and composition. Ind J AnimRes, 36: 67-69.

Harvey, W. R. 1987. Mixed model least squares and Maximum likelihood computer program- Iversion, USDA, Washington, USA.

Jennes, R. 1985. Biochemical and nutritional aspects of milk and colostrum. Chap. 5 in Lactation, B. L. Larson, editor, ed. Ames: Iowa State University Press.

Kayastha, R. B., Zaman, G. and Goswami, R. N. 2008. Factors affecting the milk 
constituents of native cattle of Assam. Ind J AnimRes, 42(2): 270-272.

Looper, M. 2016. Factors affecting milk composition of lactating cows. Agri Natural Res. (downloaded from https://www.uaex.edu/publications/pdf/ FSA-4014.pdf)

Rogers, G. L. and Stewart, J. A. 1982. The effect of some nutritional and non- nutritional on milk protein concentration and yield. Aust JDairy Tech, 37: 26.

Sarkar, U., Gupta, A. K., Sarkar, V, Mohanty, T. K., Raina, V. S. and Prasad, S. 2006. Factors affecting test day milk yield and milk composition in dairy animals. $J$ Dairying, Food Home Sci, 25: 129-132.

\section{How to cite this article:}

Gajbhiye, P.U., A.R. Ahlawat, H.A. Sharma and Parikh, S.S. 2019. Effect of Stage, Season and Parity of Lactation on Milk Composition in Gir Cattle. Int.J.Curr.Microbiol.App.Sci. 8(03): 2419-2425. doi: https://doi.org/10.20546/ijcmas.2019.803.285 